\title{
Avian influenza H5N1 in Africa: an epidemiological twist
}

\author{
Folorunso O Fasina ${ }^{\mathrm{a}, \mathrm{b},}$, Shahn P Bisschop ${ }^{\mathrm{b}}$ and Robert G Webster \\ aNational Veterinary Research Institute, Vom, Nigeria \\ bPoultry Reference Centre, Faculty of Veterinary Science, University of Pretoria, \\ Onderstepoort 0110, South Africa \\ cDivision of Virology, Department of Infectious Diseases, St Jude Children's Research Hospital, \\ Memphis, TN, USA
}

There is little information about highly pathogenic avian influenza (HPAI) H5N1 virus in Africa, where health infrastructure is inadequate and human-animal contact is

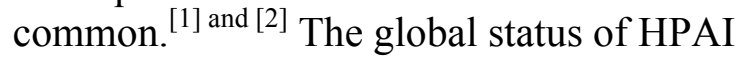
H5N1 in human beings was recently reported, ${ }^{3}$ but region and continent-specific information remains deficient. Here we describe how urbanisation and altered farming have increased the risk of HPAI H5N1 in Africa.

Sub-Saharan Africa has undergone rapid urbanisation. About $40 \%$ of the population is now urban (table). ${ }^{4}$ An estimated $60 \%$ of urban residents inhabit slums, ${ }^{5}$ and urban/peri-urban agriculture has proliferated.

Table.

Urban population as a percent of total, subSaharan Africa, 1960-2025

\begin{tabular}{|l|l|}
\hline Year & Urban (\%) \\
\hline 1960 & $11 \cdot 8$ \\
\hline 1965 & $13 \cdot 7$ \\
\hline 1970 & $15 \cdot 9$ \\
\hline 1975 & $18 \cdot 8$ \\
\hline 1980 & $22 \cdot 0$ \\
\hline 1985 & $25 \cdot 4$ \\
\hline 1990 & $29 \cdot 0$ \\
\hline 2000 & $36 \cdot 6$ \\
\hline
\end{tabular}

\begin{tabular}{|l|l|}
\hline Year & Urban (\%) \\
\hline 2010 & $43 \cdot 5$ \\
\hline 2025 & $54 \cdot 2$ \\
\hline
\end{tabular}

Source: United Nations, $1985 .^{4}$

Urban and peri-urban poultry production is increasing rapidly ${ }^{6}$ because of the unavailability of both land and economic options. ${ }^{7}$ The crowded proximity of peri-urban poultry farms, inadequate biosecurity, and burgeoning live poultry markets promote the rapid spread of disease.

The control of avian influenza H5N1 in Africa remains problematic. Human and animal disease surveillance is weak, cross-border movement is not effectively managed, and health-care systems are overtaxed by AIDS, tuberculosis, and malaria. When avian influenza $\mathrm{H} 5 \mathrm{~N} 1$ hit the African continent in early $2006,{ }^{[1]}$ and $[2]$ it was not contained for several reasons, including delayed official decisions, inexperience, lack of prompt intervention planning, poor preparedness, corruption, and hesitation by farmers to report outbreaks. Similar factors have been associated with the continued spread in Asia. ${ }^{8}$ The true situation in most African countries is unknown. Each affected country, apart from Egypt, took approximately 4 weeks to officially confirm the initial outbreak, and reporting of outbreaks 
is still delayed in most countries. ${ }^{9}$ Most cases of HPAI H5N1 infection occurred in urban and peri-urban poultry populations. ${ }^{9}$ Free-range (rural) poultry have been less affected; these birds mix freely with domestic and wild fowl and often cohabit with human beings, but their low population density appears to offset their risk of infection.

Farming conditions in Africa are similar to those in affected Asian countries, and therefore the epidemiology of H5N1 influenza is expected to be similar. To date, 40 Africans are known to have been infected, with a $40 \%$ fatality rate. Most infected individuals (80\%) were women, which may reflect the female role in food preparation.

Seasonal human influenza is grossly underreported in Africa, and therefore less-thansevere HPA1 H5N1 influenza is also unlikely to be detected. However, even the small number of reported cases portends grave danger for Africa, with its limited capacity to cope with a pandemic and its high-risk conditions and practices (including home slaughter of sick birds). ${ }^{10}$ Our assessment of the perceptions of farmers and the public showed evident knowledge gaps and the gross downplaying of avian influenza (Fasina et al, unpublished data). The general public is sometimes clearly misinformed by the government as to the true nature of avian influenza outbreaks. ${ }^{11}$ These findings have serious public-health implications, because farmers prepare poultry and poultry products sold to the public, usually without inspection.

The prolonged continuous circulation of HPAI $\mathrm{H} 5 \mathrm{~N} 1$ virus in domestic poultry in Asia is unprecedented. The virus has evolved into multiple genetic lineages that differ antigenically. ${ }^{12}$ The Qinghai strain, the predominant variant in Africa, has acquired several troubling properties, including respiratory rather than faecal transmission in poultry, increased thermal stability, and a PB2 gene mutation associated with pathogenicity in mammals, including human beings. ${ }^{13}$ Because there are fewer domestic waterfowl in Africa than in Asia, it is unknown whether they can perpetuate the virus through the warm season. It is also not known whether HPA1 H5N1 is being maintained in African birds or periodically reintroduced.

WHO identified five priorities in the fight against avian influenza: reduced human exposure, strengthened surveillance, intensified rapid containment, enhanced response capacity, and coordinated global research. ${ }^{14}$ However, Africa's ability to accomplish all of these goals is doubtful. The risk of human infection in Africa is increased by reluctant, delayed, or deficient reporting, poor surveillance, inefficient diagnosis, denial of outbreaks, crisis-driven disease management, poor communication of risks, inter-ethnic crises, sociocultural issues, and the politicisation of avian influenza H5N1. The Asian strain of highly pathogenic H5N1 continues to ravage the African continent and reports of new outbreaks persist, although some countries claim to be free of the virus. Each African nation must realistically assess its status (especially its borders, wet markets, and displaced/peri-urban populations), conduct regular active surveillance, and be more forthcoming with data. International agencies and donor nations should be ready to assist African nations that are developing or in transition. An uncontrolled epizootic of avian influenza in any nation is a threat to all nations.

We declare that we have no conflicts of interest.

These studies were supported in part by grant AI 70005 (RGW). We thank Sharon Naron for editorial assistance. 


\section{References}

1 The Lancet Infectious Diseases, Avian influenza goes global, but don't blame the birds, Lancet Infect Dis 6 (2006), p. 185. 2 M Enserink, Avian influenza: H5N1 moves into Africa, European Union, deepening global crisis, Science 311 (2006), p. 932.

3 CDC, Update: influenza activity-United States and worldwide, May 20-September 15, 2007, Morb Mortal Wkly Rep 56 (2007), pp. 1001-1004.

4 Department of International Economic and Social Affairs, Estimates and projections of urban, rural and city populations, 1965-2025. the 1982 assessment, United Nations, New York (1985).

5 AK Tibaijuka, An opening address at the Second COASAD General Assembly and PanAfrican Congress on Food Security, Trade and Sustainable Development http://www.unhabitat.org/content.asp?cid=135 $2 \&$ catid $=14 \&$ typeid $=8 \&$ subMenuId $=0$ (accessed Sep 17, 2007).. 6 Food and Agricultural Organisation, GLIPHA. Statistics and data on animal resources in the world http://0www.fao.org.innopac.up.ac.za:80/ag/aga/gliph a/index.jsp (accessed Nov 8, 2006). 7 F Dolberg, A livestock development approach that contributes to poverty alleviation and widespread improvement of nutrition among the poor, Livestock Research for Rural Development 13 (5) (2001) http://0-

www.cipav.org.co.innopac.up.ac.za:80/lrrd/lrrd 13/5/dolb135.htm (accessed Sept 17, 2007).
8 JA Pawitan, Averting avian influenza pandemic: SOS from a developing country, Lancet Infect Dis 6 (2006), pp. 756-757. 9 World Organisation for Animal Health, Update on avian influenza in animals (Type H5) http://0www.oie.int.innopac.up.ac.za:80/downld/avian \%20influenza/A AI-Asia.htm (2007) (accessed Sept 17, 2007)..

10 The Lancet Infectious Diseases, Influenza pandemic preparation - much still to be done, Lancet Infect Dis 6 (2006), p. 315.

11 The Guardian, Avian influenza: the facts and the fallacies, by Badmus, poultry group boss, March 26, 2007

http://www.guardiannewsngr.com/business/arti cle13/260307 (accessed Sept 17, 2007).. 12 RG Webster and EA Govorkova, H5N1 influenza - continuing evolution and spread, $N$ Engl J Med 355 (2006), pp. 2174-2177. 13 JS Peiris, M de Jong and Y Guan, Avian influenza virus (H5N1): a threat to human health, Clin Microbiol Rev 20 (2007), pp. 243 267.

14 WHO, Avian influenza and human pandemic influenza. Summary report of meeting held in Geneva, Switzerland 7-9 November 2005 http://0www.who.int.innopac.up.ac.za:80/mediacentre /events/2005/avian_influenza/summary_report Nov_2005_meeting.pdf (accessed Sept 17, 2007).. 


\section{doi:10.1016/S1473-3099(07)70244-X (2) Cilte ur Lirık Usirly Dol}

Copyright (C) 2007 Elsevier Ltd All rights reserved.

${ }^{*}$ Folorunso O Fasina, Shahn P Bisschop, Robert G Webster

National Veterinary Research Institute, Vom, Nigeria (FOF);

Poultry Reference Centre, Faculty of Veterinary Science,

University of Pretoria, Onderstepoort 0110, South Africa

(FOF, BPS); and Division of Virology, Department of Infectious

Diseases, St Jude Children's Research Hospital, Memphis, TN, USA

(RGW)

daydupe2003@yahoo.co.uk 